\title{
Prevalence of Mycoplasma hyorhinis contamination in tissues samples from cancer patients: A Brief Report
}

\author{
Mohammad Reza Zinatizadeh*1, Zahra Masoumalinejad ${ }^{2}$, Farzaneh Parnak $^{3}$
}

1. Department of Genetics, Faculty of Science, Tonekabon Branch, Islamic Azad University, Mazandaran, Iran

2. Department of Microbiology, Sirjan Branch, Islamic Azad University, Sirjan, Iran

3. Department of Biology, Sirjan Branch, Islamic Azad University, Sirjan, Iran

\section{KEYWORDS}

M. hyorhinis

cancer

gastric

breast

lung

Article Info

Received 2018/09/22;

Accepted 2018/11/03;

Published Online 2019

\section{ABSTRACT}

Infectious agents cause $15-20 \%$ of cancers worldwide. The contamination of infectious agents may be caused by a local chronic inflammatory response or tumorization. Mycoplasma contamination can interfere with biological agents and cause DNA damage which affects gene expression, disrupts the cell-cycle control and apoptotic responses. Mycoplasmas are widely distributed in nature; some mycoplasmas have the ability to penetrate into the cell and cause sever disease. Most mycoplasmas are known to infect the cell culture media, which is difficult to detect the contamination.

M. hyorhinis is one of the main reasons the Mycoplasma contamination in tissues samples from cancer patients. Mycoplasma is related to human cancers and some other human diseases. Several studies have shown that $M$. hyorhinis potentially plays a role in esophageal, gastric, lung, breast, glioma, colon, and prostate cancers. The prevalence of $M$. hyorhinis in various tissues leads to cancer progression. Therefore, it is necessary to pay more attention to this mycoplasma agent in order to control and understand its mechanism.

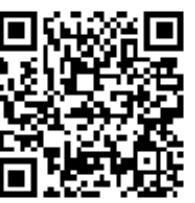

Corresponding Information: Mohammad Reza Zinatizadeh, Department of Genetics, Tonekabon Branch Islamic Azad University. Email: zinati3333@gmail.com

Copyright $\odot$ 2019. This is an open-access article distributed under the terms of the Creative Commons Attribution-noncommercial 4.0 International License which permits copy and redistribute the material just in noncommercial usages, provided the original work is properly cited.

\section{Introduction}

Infectious agents cause $15-20 \%$ of cancers all around the world $(1,2)$. The contamination of infectious agents may be caused by a local chronic inflammatory response, or by tumorization through viral or bacterial protein products (3-5). Different types of infectious agents have been identified for various cancers (6). Mycoplasma contamination can interfere with biological agents and cause DNA damage which affects gene expression, disrupts the cell-cycle control and apoptotic responses (7-9). $M$. hyorhinis can increase the invasion and migration of prostate epithelial cells which is associated with arthritis, cervicitis, infertility and human cancer that is a common contamination of stem cells (10-14).
M. hyorhinis belongs to the class Mollicutes that are small and wall-free. In the 1960s, the first study has reported the association between mycoplasma infection and leukemia (15).

It has been reported that $M$. hyorhinis is the most usual contamination of cell cultures in association with human cancers, such as (esophageal, gastric, lung, breast, glioma, colon cancer, and prostate) (10, 16-17). Namiki and colleagues reported the occurrence of $M$. hyorhinis infection in malignant of the benign human prostate (BPH-1) in cell culture $(10,17-18)$. Besides, Urbanek and his colleagues, using serological test showed positive tests of $M$. hyorhinis for more than 
thirty percent benign prostatic hyperplasia $(\mathrm{BPH})$ and more than fifty percent prostatic cancer tissues (19). Moreover, these bacteria are able to increases the cell migration and cell invasion of gastric cancer cells and melanoma cells (10, 16-17).

Dong and his research group in 1980 performed studies on monoclonal PD4 antibody via mice immunization with the gastric cancer cell, then the mycoplasma antigen was detected by PD4, which is a lipoprotein of M. hyorhinis called P37 and does not have any homology with human proteins (17-21).

In a study by Huang et al., using this antibody for immunohistochemistry, the prevalence of the mycoplasma species was evaluated in tissues, the prevalence of this bacterium was more than fifty percent in gastric cancer, twenty-eight percent in chronic superficial gastritis, thirty percent in gastric ulcer and thirty-seven percent in intestinal metaplasia. However, in colon cancer, the prevalence was fifty percent but $20 \%$ reported in the adenomatous polyp, which showed the increased prevalence of $M$. hyorhinis as a disease progressive (16).

The study of Duan displayed that this mycoplasma infection depends on the interaction of p37 protein, which is a major membrane protein of $M$. hyorhinis and host ANXA2 through the Nterminal. Also, polyclonal antibodies can block p37 and cause decreasing contamination and promoting the migration of $M$. hyorhinis from the gastric cancer cell, respectively (22).

Studies have shown a direct interaction between the mycoplasma contamination and cancer metastasis such that p37 invasion and metastatic gastric cancer cells will increase both in vitro and in vivo $(19,23)$.

\section{M. hyorhinis in different tissues}

Information related to data collection from different cancer registries via $M$. hyorhinis have been published in various articles (Table1). In 1995, in their first study, Sasaki et al. reported a high prevalence of mycoplasmas in tumor tissue and found $48 \%$ of gastric adenocarcinoma samples infected by M. hyorhinis (24). In 2001, Huang and colleagues conducted a large screening of different cancer tissues using IHC and reported the rates of $M$. hyorhinis infection that was $40-53 \%$ in the lung, breast cancer, esophageal and glioma tissue samples. Atogether, increased mycoplasma infection ratios were detected in gastric carcinoma (56\%) compared with other gastric diseases (28$37 \%$, depending on the pathology), and colon carcinoma $(55 \%)$ in comparison to tissue derived from adenomatous polyps (21\%). Importantly, the authors found that $M$. hyorhinis infection significantly increased in well-differentiated tissues compared with poorly differentiated tissues whereas the most studies report the increased mycoplasma infection in high versus low-grade samples (16).

In 2010, the statistical analysis of Yang's study indicated that the presence of M. hyorhinis was $64 \%$ in gastric cancer tissues and significant relationship was observed among Mycoplasma infection. By increasing EGFR and ERK1 / 2 phosphorylation, $M$. hyorhinis can probably promote the migration of tumor cells, invasions, and metastases in vitro and in vivo. The migration of infected cells can be inhibited by an antibody against the $M$. hyorhinis p37 protein (17).

In 2010, Elisabetta Mariotti et al. reported the cancer cells infected by $M$. hyorhinis and there was the highest number of CD133+ cells compared to the same cells, whereas they were not effective when exposed to the antibiotic treatment. Their results showed when $\mathrm{M}$. hyorhinis caused infection the percent of CD133 positive cells increased.. Therefore, $M$. hyorhinis infection plays an important role in the quality of human colon cancer cell lines, leading to false positives in the expression of cancer stem cells, which presents the expression of CD133 (25).

The Mycoplasma infection was compared in prostate biopsies from healthy individuals and $\mathrm{BPH}$ patients, patients with elevated PSA levels, highgrade prostatic intraepithelial neoplasy (HGPIN) and prostate cancer. Patients with prostate cancer or HGPIN indicated an increase in seropositivity for $M$. hominis and M. hyorhinis antibodies compared with individuals suffering from BPH $(19,26-27)$. 


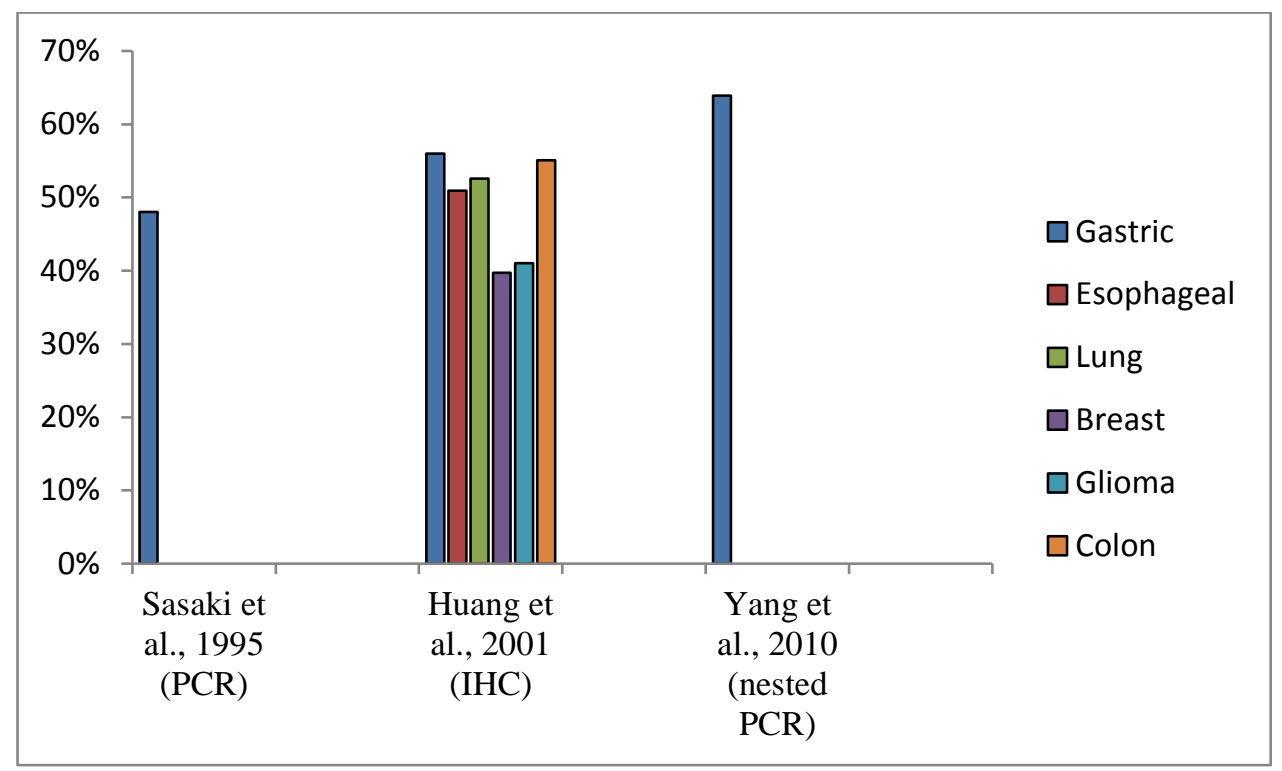

Figure 1: Prevalence of $M$. hyorhinis in tissue samples from cancer patients

\section{Conclusion}

The prevalence of $M$ hyorhinis in various tissues leads to cancer progression in patients with cancer. Therefore, it is necessary to pay more attention to this mycoplasma agent in order to control and understand its mechanism.

\section{References}

1. Jemal A, Siegel R, Ward E, Murray T, Xu J, Thun MJ: Cancer statistics, 2007. CA Cancer J Clin 2007, 57:43-66.

2. Zinatizadeh MR. 2017. "Health Monitoring of Laboratory NIH Mice produced in Razi Institute Karaj to Mycoplasma Muris agent" M.Sc dissertation, University of Tonekabon.

3. Koraitim MM, Metwalli NE, Atta MA, el-Sadr AA: Changing age incidence and pathological types of schistosomaassociated bladder carcinoma. J Urol 1995, 154:1714-6.

4. Hanto DW, Frizzera G, GajlPeczalska KJ, Sakamoto K, Purtilo DT, Balfour HH Jr,Simmons RL, Najarian JS: Epstein-Barr virus induced $\mathrm{B}$ cell lymphoma after renal transplantation. Acyclovir therapy and transition from polyclonal to monoclonal B-cell proliferation. NEJM 1982, 306:913-8.
5. Reeves WC, Brinton LA, Garcia M, Brenes MM, Herrero R, Gaitan E, Tenorio F, de Britton RC, Rawls WE: Human papillomavirus infection and cervical cancer in Latin America. NEJM 1989, 320:1437-41.

6. Ferlay J, Shin HR, Bray F, Forman D, Mathers C, Parkin DM: Estimates of worldwide burden of cancer in 2008: GLOBOCAN 2008. Int J Cancer 2008, 2010(127):2893-2917.

7. Drexler HG, Uphoff CC, Dirks W, Macleod RAF: Mix-ups and mycoplasma: the enemies within. Leuk Res 2002, 26:329-333.

8. Drexler HG, Uphoff CC: Mycoplasma contamination of cell cultures: incidence, sources, effects, detection, elimination, prevention. Cytotechnology 2002, 39:23-38.

9. Sun $\mathrm{G}, \mathrm{Xu} X$, Wang $Y$, Shen $X$, Chen Z, Yang J, et al. Mycoplasma pneumoniae Infection Induces Reactive Oxygen Species and DNA Damage in A549 Human Lung Carcinoma Cells. Infect Immun. 2008; 76:4405-13. doi: 10.1128/IAI.00575-08 PMID: 18663006

10. Namiki K, Goodson S, Porvasnik S, Allan RW, Iczkowski KA, Urbanek C, 
et al. Persistent Exposure to Mycoplasma Induces Malignant Transformation of Human Prostate Cells. PLoS One. 2009; 4:e6872. doi: 10.1371/journal.pone.0006872 PMID: 19721714.

11. Rogers MB. Mycoplasma and cancer: in search of the link. Oncotarget. 2011; 2:271-3. PMID:21508438.

12. Cazanave C, Manhart LE, Bebear C. Mycoplasma genitalium, an emerging sexually transmitted pathogen. Med Mal Infect. 2012; 42:381-92. doi: 10.1016/j.medmal.2012.05.006 PMID: 22975074

13. Chrisment D, Charron A, Cazanave C, Pereyre S, Bébéar C. Detection of macrolide resistance in Mycoplasma genitalium in France. $\mathrm{J}$ Antimicrob Chemother. 2012; 67:2598-601. doi: 10.1093/jac/ dks263 PMID: 22773740

14. Roediger WE. Intestinal mycoplasma in Crohn's disease. Novartis Found Symp. 2004; 263:85-93. PMID: 15669636

15. Paton GR, Jacobs JP, Perkins FT: Chromosome changes in human diploidcell cultures infected with Mycoplasma. Nature 1965, 207:43-45.

16. Huang S, Li JY, Wu J, Meng L, Shou CC. Mycoplasma infections and different human carcinomas. World J Gastroenterol2001; 7:266-269.

17. Yang H, Qu L, Ma H, Chen L, Liu $\mathrm{W}$, Liu C, et al. Mycoplasma hyorhinis infection in gastric carcinoma and its effects on the malignant phenotypes of gastric cancer cells. BMC Gastroenterol 2010;10:132.

18. Kornspan JD, Tarshis M, Rottem S. Invasion of melanoma cells by Mycoplasma hyorhinis: enhancement by protease treatment. Infect Immun 2010;78:611-617.

19. Dong ZW, Wan WH, Li ZP, Qiu WR, Wei SM. A monoclonal antibodies PD4 against gastric cancer cell line
MGC803.ShengwuHuaxueZazhi 1985;1:52-58.

20. Ning JY, Sun GX, Huang S, Ma H, An P, Meng L, et al. Identification of antigens by monoclonal antibody PD4 and its expression in Escherichia coli. World $\mathrm{J}$ Gastroenterol 2003;9:2164-2168.

21. Sippel KH, Robbins AH, Reutzel R, Boehlein SK, Namiki K, Goodison S, Agbandje-McKenna M, Rosser CJ, McKenna R: Structural insights into the extracytoplasmic thiamine-binding lipoprotein $\mathrm{p} 37$ of Mycoplasma hyorhinis. J Bacteriol 2009, 191:2585-2592.

22. Urbanek C, Goodison S, Chang M, Porvasnik S, Sakamoto N, Li CZ, et al. Detection of antibodies directed atM. hyorhinis p37 in the serum of men with newly diagnosed prostate cancer. BMC Cancer. 2011; 11:233. doi: 10.1186/14712407-11-233 PMID: 21663671

23. Duan H, Chen L, Qu L, Yang H, Song SW, Han Y, et al. Mycoplasma hyorhinis infection promotes NFkBdependent migration of gastric cancer cells. Cancer Res. 2014; 74:5782-94. doi: 10.1158/0008-5472.CAN-14-0650 PMID: 25136068

24. Gong M, Meng L, Jiang B, Zhang J, Yang H, Wu J, Shou C: p37 from Mycoplasma hyorhinis promotes cancer cell invasiveness and metastasis through activation of MMP-2 and followed by phosphorylation of EGFR. Mol Cancer Ther 2008, 7:530-537.

25. Sasaki Y, Blanchard A, Watson HL, Garcia S, Dulioust A, Montagnier L, Gougeon ML. In vitro influence of Mycoplasma penetrans on activation of peripheral $\mathrm{T}$ lymphocytes from healthy donors or human immunodeficiency virus-infected individuals. Infection and immunity. 1995 Nov 1;63(11):4277-83.

26. Mariotti E, Gemei M, Mirabelli P, D'Alessio F, Di Noto R, Fortunato G, Del Vecchio L. The percentage of CD133+ cells in human colorectal cancer cell lines is influenced by Mycoplasma hyorhinis 
infection. BMC cancer. 2010 Mar 30;10(1):120.

27. Barykova YA, Logunov DY, Shmarov MM, Vinarov AZ, Fiev DN, Vinarova NA, Rakovskaya IV, Baker PS,
Shyshynova I, Stephenson AJ, Klein EA. Association of Mycoplasma hominis infection with prostate cancer. Oncotarget. 2011 Apr 4;2(4):289-97.

\section{How to cite this article:}

Zinatizadeh M R, Masoumalinejad Z, Parnak F. Prevalence of Mycoplasma hyorhinis contamination in tissues samples from cancer patients: A Brief Report. Mod Med Lab J. 2019; 2 (1) :91-95 